\title{
Stress level experienced by participants in realistic simulation: a systematic review
}

\author{
Nível de estresse experimentado por participantes em simulação realística: uma revisão sistemática \\ Nivel de estrés experimentado por participantes en simulación realista: una revisión sistemática
}

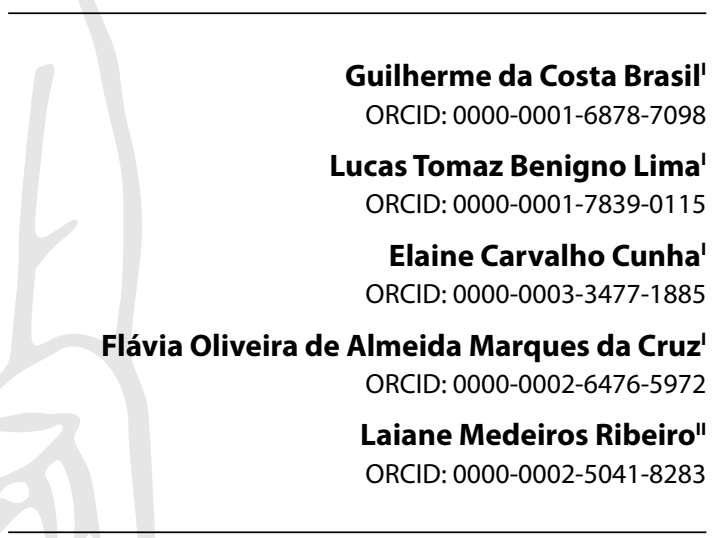

'Centro Universitário do Distrito Federal. Brasilia, Distrito Federal, Brazil.

"Universidade de Brasília. Brasília, Distrito Federal, Brazil.

How to cite this article: Brasil GC, Lima LTB, Cunha EC, Cruz FOAM, Ribeiro LM. Stress level experienced by participants in realistic simulation: a systematic review. Rev Bras Enferm. 2021;74(4):e20201151. https://doi.org/10.1590/0034-7167-2020-1151

Corresponding author: Guilherme da Costa Brasil

E-mail: guilhermecostabrasil@hotmail.com

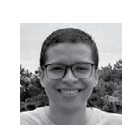

EDITOR IN CHIEF: Antonio José de Almeida Filho ASSOCIATE EDITOR: Ana Fátima Fernandes

Submission: $10-27-2020$

Approval: 01-11-2021

\begin{abstract}
Objectives: to identify the available evidence regarding stress levels experienced by participants in education based on a realistic simulation. Methods: systematic review that included randomized clinic trials on electronic databases: Cumulative Index to Nursing and Allied Health Literature, Cochrane Library, Latin-American and Caribbean Literature in Health Sciences, LIVIVO, PubMed, Scopus, and Web of Science. The additional search was performed on Google Scholar and Open Grey. All searches occurred on September 24, 2020. The methodologic quality of the results was evaluated by the Cochrane Collaboration Risk of Bias Tool. Results: eighteen studies were included, which evaluated the participants'stress using physiologic, self-reported measures, or the combination of both. Stress as experienced in a high level in simulated scenarios. Conclusions: evidence of the study included in this systematic review suggest that stress is experienced in a high level in simulated scenarios. Descriptors: Simulation Training; Stress, Psychological; Patient Simulation; Systematic Review; Education.
\end{abstract}

\section{RESUMO}

Objetivos: identificar as evidências disponíveis sobre o nível de estresse experimentado por participantes em educação baseada em simulação. Métodos: revisão sistemática que incluiu ensaios clínicos randomizados nas bases eletrônicas: Cumulative Index to Nursing and Allied Health Literature, Cochrane Library, Literatura Latino-Americana e do Caribe em Ciências da Saúde, LIVIVO, PubMed, Scopus e Web of Science. A busca adicional foi realizada no Google Scholar e OpenGrey. Todas as buscas ocorreram no dia 24 de setembro de 2020. A qualidade metodológica dos estudos foi avaliada pelo Cochrane Collaboration Risk of Bias Tool. Resultados: foram incluídos 18 estudos, os quais avaliaram o estresse dos participantes por meio de medidas fisiológicas, autorreferidas ou combinação de ambas. O estresse foi experimentado em nível elevado em cenários simulados. Conclusões: as evidências dos estudos incluídos nesta revisão sistemática sugerem que o estresse é experimentado em nível elevado em cenários simulados.

Descritores: Simulação; Estresse Psicológico; Simulação de Paciente; Revisão Sistemática; Educação.

\section{RESUMEN}

Objetivos: identificar evidencias disponibles sobre el nivel de estrés experimentado por participantes en educación basada en simulación. Métodos: revisión sistemática que incluyó ensayos clínicos randomizados en las bases electrónicas: Cumulative Index to Nursing and Lallied Health Literature, Cochrane Library, Literatura Latinoamericana y de Caribe en Ciencias de la Salud, LIVIVO, PubMed, Scopus y Web of Science. Búsqueda adicional fue realizada en el Google Scholar y OpenGrey. Todas las búsquedas ocurrieron en el día 24 de septiembre de 2020. La calidad metodológica de los estudios fue evaluada por el Cochrane Collaboration Risk of Bias Tool. Resultados: fueron incluidos 18 estudios, los cuales evaluaran el estrés de los participantes por medio de medidas fisiológicas, autoinformados o combinación de ambos. El estrés fue experimentado en nivel elevado en escenarios simulados. Conclusiones: las evidencias de los estudios incluidos en esta revisión sistemática sugieren que el estrés es experimentado en nivel elevado en escenarios simulados.

Descriptores: Simulación; Estrés Psicológico; Simulación de Paciente; Revisión Sistemática; Educación. 


\section{INTRODUCTION}

The realistic simulation has become a training pattern in graduate and postgraduate courses, in different health scenarios. The gains are related to safety, competence, teamwork, clinical reasoning, knowledge retention, satisfaction and development of technical, and non-technical skills ${ }^{(1-4)}$.

However, the confidence and proficiency level acquired by the participants is variable ${ }^{(5-9)}$, since such experiences may be stressful and negatively impact their performance making the environment unfavorable to learning and development of clinical skills. We discuss that this scenario may distance from the objective of inspiring confidence, generate learning, and conduct a positive self-criticism in the long run ${ }^{(10)}$.

Any intrinsic or extrinsic stimulus that evokes a biological answer is known as stress ${ }^{(11)}$. Recent studies observed that, in simulated scenarios, it was detrimental to the performance of the participants ${ }^{(6,12)}$, while other studies did not show a negative impact ${ }^{(13-14)}$. Thus, the fact that it is harmful or beneficial, or if it is even experienced, is still low since there is also the hypothesis that the stress and anxiety evoked are educational tools $s^{(10,15)}$.

Studies reviews conducted both with animals and human beings showed that the hormonal alteration involved in stress may influence learning and memory in different ways, depending on time and hormonal release profile ${ }^{(11-16)}$. Primary studies have already identified that increased plasma cortisol after prolonged stress has a decrease in memory, which improves when the plasma cortisol level decreases ${ }^{(17)}$. On the other hand, under specific conditions, stress may improve memory over a period of time ${ }^{(18)}$.

It can be analyzed through psychologic measures, such as validated scales of self-perception; and physiological, such as heart rate variability, salivary cortisol and salivary amylase $\mathrm{e}^{(19-21)}$.

When perceived stress is evaluated in students, the answer may be the decrease of self-confidence when they are experiencing the first clinical experience ${ }^{(22)}$. In contrast, high anxiety, added to other emotional stress agents, has been described as having a positive correlation with performance improvement, even though the training took place many months before ${ }^{(23)}$. When analyzing studies related to the students' emotional state, clinical performance, and self-confidence is possible to verify inconsistency and lack of clarity regarding the presence of stress and its association with performance ${ }^{(24-25)}$.

Therefore, knowing that simulation strategy is widely used in health teaching, there is a need to investigate the stress experienced during its application. Thus, it is relevant to identify if there is an increase in the stress level during a simulation session and if there is an improvement or worsening in the participants' performance.

\section{OBJECTIVES}

To identify pieces of evidence available about the stress level experienced by participants in education based on simulation.

\section{METHODS}

\section{Protocol and register}

This systematic review was conducted according to the items of the Preferred Reporting Items for Systematic Reviews and
Meta-Analyses - PRISMA ${ }^{(26)}$. The protocol was registered in the International Prospective Register of Systematic Reviews under the number CRD42019136297.

\section{Eligibility criteria}

The question was guided by the PICO process, considering "P" (patient or problem) as participants in simulation; "I" (intervention) as a realistic simulation; " $\mathrm{C}$ " (control) was not applied; and "O" (outcome), stress level. Thus, the question was: What was the stress level experienced by participants in education based on the simulation?

In this systematic review, the following studies that evaluated the stress were included: (1) through the design of a randomized clinical trial (RCT); (2) in realistic simulations performed with students from different health areas (medicine, nursing, physiotherapy, paramedic); (3) in simulations for the training of medical resident professionals; (4) in simulations that included graduated health professionals; (5) in simulations in institutional laboratories - hospital scenario, in situ, and low, medium and high fidelity simulation; (6) by subjective and/or objective measures.

The studies were excluded by the following criteria: (1) they did not evaluate the stress during the simulation, but other factors that could interfere such as the influence of a training seminar on the stress change in the simulation, the connection between the improved learning tests and the response to cortisol, and the addition of acute stressors to simulated scenarios on impact on clinical performance; (2) not an RCT; (3) not a realistic simulation; (4) not virtual simulation; (5) focused on evaluating anxiety.

\section{Databases and search strategy}

The studies were identified using a search strategy for each of the following electronic databases: Cumulative Index to Nursing and Allied Health Literature (CINAHL), Cochrane Library, LatinAmerican and Caribbean Literature in Health Sciences (LILACS), LIVIVO, PubMed, Scopus, and Web of Science. The reference list of the selected studies was analyzed manually to identify those potentially relevant that could have been lost in electronic searches in the databases. Furthermore, we performed a search in the grey literature using Google Scholar and OpenGrey. Duplicated references were removed using the EndNote. All searches on electronic databases occurred on September 24, 2020, which processes are showed in Chart 1.

\section{Selection of studies}

The selection of studies occurred in two stages through the online application Rayyan (Qatar Computing Research Institute). In the first stage, researchers independently examined titles and abstracts of all studies recovered on the database and identified those that seemed to meet the inclusion criteria. In the second stage, the same researchers independently read the complete text of all works selected and excluded those that did not meet the inclusion criteria. Any differences in this stage were resolved by discussion and consensus between the three reviewers. 
Chart 1 - Search strategies on electronic databases, Brasilia, Distrito Federal, Brazil, 2020

\begin{tabular}{|c|c|}
\hline Databases & Key words \\
\hline PubMed & 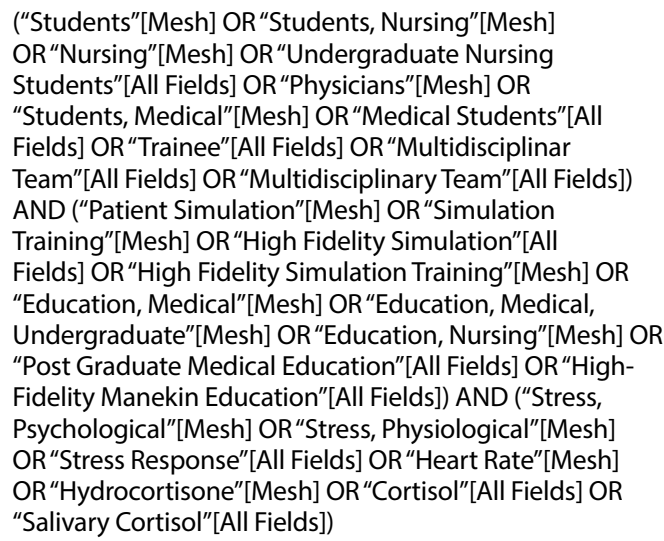 \\
\hline LILACS & $\begin{array}{l}\text { (tw:(estudantes OR estudiantes OR students)) AND } \\
\text { (tw:(simulação OR simulación OR simulation)) }\end{array}$ \\
\hline $\begin{array}{c}\text { Cochrane } \\
\text { Library, } \\
\text { CINAHL, } \\
\text { LIVIVO, } \\
\text { Scopus, } \\
\text { Web of } \\
\text { Science. }\end{array}$ & 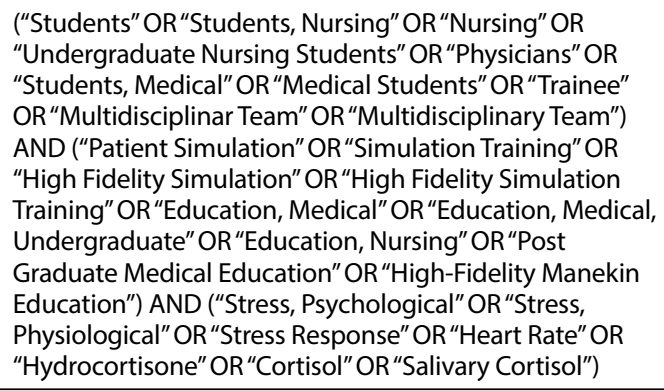 \\
\hline $\begin{array}{l}\text { Google } \\
\text { Scholar, } \\
\text { OpenGrey. }\end{array}$ & ("students" AND "simulation") \\
\hline
\end{tabular}

\section{Data collection process}

Two researchers independently collected data from the studies that included the characteristics of the participants (groups, samples, student or practitioners), characteristics of the study (authors, Country, year of publication, objective, design, and randomization, intervention (a type of simulation, simulator, area of skill), collection (instrument or measure for collection of the stress), and characteristics of the results (main results and main inclusions). Any differences were solved and discussed in mutual agreement. A third author was involved when we needed to take a final decision. If the requested data was not complete, we contacted the authors to obtain any relevant information.

\section{Risk of study bias}

Two researchers independently conducted the risk of bias evaluation of the studies included in this systematic review. Again, any differences were solved and discussed in mutual agreement. A third author was involved when we needed to take a final decision.

We used the Cochrane Collaboration Risk of Bias Tool (RoB 2 tool) to evaluate the risk of bias in the included studies, which allows us to evaluate the process of generating sequences, hiding allocation, hiding participants, staff and evaluators, incomplete results data, and selective reports.

\section{Summary of results}

Heterogeneity among studies was evaluated considering the methodologic characteristics (the type of intervention, groups of participants, and risk of bias) and statistics (outcome measures). Therefore, due to the heterogeneity among the included studies, the quantitative synthesis was not held. In line with the objectives of the review, we analyzed the studies' outcomes and reports included according to the characteristics of the simulation and type of evaluation of stress.

\section{RESULTS}

The initial bibliographic search identified 4,946 studies in 7 electronic databases. The search on Google Scholar selected the first 100 references found for reading titles and abstracts, and the search on OpenGrey returned a total of 43 references. After a complete reading, 18 studies met all the eligibility criteria and were included in this systematic review. Figure 1 shows the identification process, screening, and inclusion of studies.

All works included are RCT, in which 15 used some physiologic pattern in the evaluation of the stress and, among them, only 4 included measures to minimize gauging or reported the exclusion of a participant for not adopting measures that could alter the physiologic parameters. Among the measures and care, we had measurement of progesterone and estrogen in salivary samples ${ }^{(27)}$, guidance on food, alcohol, caffeine, and nicotine consumption half an hour before the evaluation and not exercising 24 hours before collection ${ }^{(28)}$, past illnesses that could induce related changes or even worsen due to stress, previous psychiatric illness, if patients were not under treatment, use of hormones like steroids or hormone replacement therapy, verification if any participant worked the night shift the day before the simulation and if the participants had been faced with a stressful event the day before or the day of the simulation ${ }^{(29)}$, exclusion of students with a history of beta-blocker use and a history of recent antidepressant use ${ }^{(30)}$, exclusion of those who used beta-agonist inhalers, steroids, oral contraceptive pill, and caffeine ${ }^{(31)}$. Of the studies found, 13 were in the medical field, and only 2 surveys carried out the study with a team from different areas, like doctors, nurses, paramedics and ambulance drivers $^{(29)}$, and medical and nursing students ${ }^{(24)}$. Six studies evaluated the stress in the simulation with practitioners who graduated in medicine

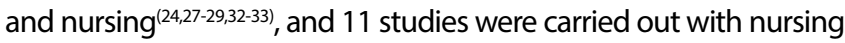
undergraduate students and Medicine $\mathrm{e}^{(30-31,34-42)}$.

In self-perceived stress, one study identified the simulation significantly increasing stressors factors ${ }^{(34)}$. In another study, a scenario in which there was death was more stressful than a survival scenario ${ }^{(27)}$.

The perception of stress significantly increased in obstetric scenarios comparing the baseline level and the post-simulation $(p<0.0001)$. There was a significant negative correlation between the general perception of stress/overload, and the time of execution $(r=-0.18, p<0.05)$, indicating that more stress/overload was associated with less practice time in scenarios with or without previous instruction to deal with stress ${ }^{(32)}$.

In the case the students received theoretical instructions in expository class to deal with stress, there were reports with significantly fewer cases of stress/overload perceived, compared to the group that did not receive instructions (difference in perceived 
tension, $\mathrm{p}=0.04)^{(38)}$. A study evaluated the perceived skills of an individual in dealing with the stressor during the simulation, which value increased when compared the moment immediately before to the moment immediately after the end of the scenario(36).

The relationship between stress and participants' performance was investigated in eight studies. There was no significant difference in the performance when the participants were observed by one or five observers $(p=0,14)^{(30)}$. There was not a significant difference in the performance during the evaluation of stress between the clinic simulation and in situ simulation $(p=0.36)^{(32)}$ nor concerning the stress of low and high fidelity scenarios $(p=0.17)^{(36)}$; we also did not observe a significant difference in the performance between participants that received instruction with an expositive class to deal with the stress and those that received (no $p$ value described in the study): although stress decreased with instruction, performance did not improve ${ }^{(38)}$.

In postpartum neonatal resuscitation scenarios with death or survival, performance was similar, and we did not see any significant difference between medical residents of the 1 st. and 2 nd. years compared to those of $3 \mathrm{rd}$. or 4th. years (death scenario, $p=0.23$; survival scenario, $p=0.33)^{(27)}$. Participants that received a previous instruction in suture had a higher performance than the control-group $(p<0.001)^{(40)}$. There was not a significant difference between the performance of the group in the scenario with a standardized patient (a person trained to present illness in a standardized manner) and the group that used the simulator ( $p=$ 0.744 ), though, in the participant's self-perception, a standardized patient adds higher stress ${ }^{(41)}$.

In a laparoscopic training session, participants had a better performance with instructions than without previous instructions $(p<0.001)$, which was correlated with the increase of heart rate ${ }^{(42)}$. Participants with a better performance expose elevation in heart rate that is associated with greater self-efficacy and satisfaction ${ }^{(40)}$.

The main characteristics of the included studies are presented in Chart 2.

\section{Summary of the data}

All analyzed studies evaluated the stress of the participants using physiologic self-reported measures or a combination of both. The risk of bias in the studies was evaluated as low, high, or a little unclear (Figure 2). Based on its objectives, the stress investigation occurred in simulations of different areas (pediatrics, neonatology, obstetrics, clinic simulation, emergency, surgical, death scenarios, and communication of adverse news) and distinct professions and teams.

Two studies compared the simulation with other learning strategies such as the practice in the laboratory $^{(34)}$ and learning interactive sessions ${ }^{(24)}$. Two other studies evaluated scenarios with death and survival, showing that the scenarios with death did not significantly increased the stress compared to the survival scenario ${ }^{(27,35)}$.
The other studies evaluated simulation with another aspect within the simulation itself, such as go under more trainings or not $^{(29)}$, have the presence of one or five observers ${ }^{(30)}$, have an instructor before the simulation or not ${ }^{(42)}$, go under repeated sessions of simulation or not ${ }^{(1)}$, simulation in situ and clinic simulation $^{(32)}$, use of standardized patient or simulator ${ }^{(41)}$, have training on communication or not ${ }^{(28)}$, have a previous training on how to deal with stress or not ${ }^{(38)}$, high or low fidelity simulation ${ }^{(36)}$, previous training on suture or not ${ }^{(40)}$, be leader of member of the simulation team ${ }^{(33)}$, be criticized during the scenarios or not $^{(37)}$, high or low-stress scenario ${ }^{(39)}$, silent or noisy simulation ${ }^{(31)}$.

Using different ways to measure the physiologic stress, heart rate and cortisol levels show patterns of change over time, which increase and decrease differently, suggesting that, when we interpret these patterns, the analysis should be separated ${ }^{(28)}$. Two studies identified that the stress results were similar when measuring with salivary cortisol and with validated instruments ${ }^{(32,36)}$.

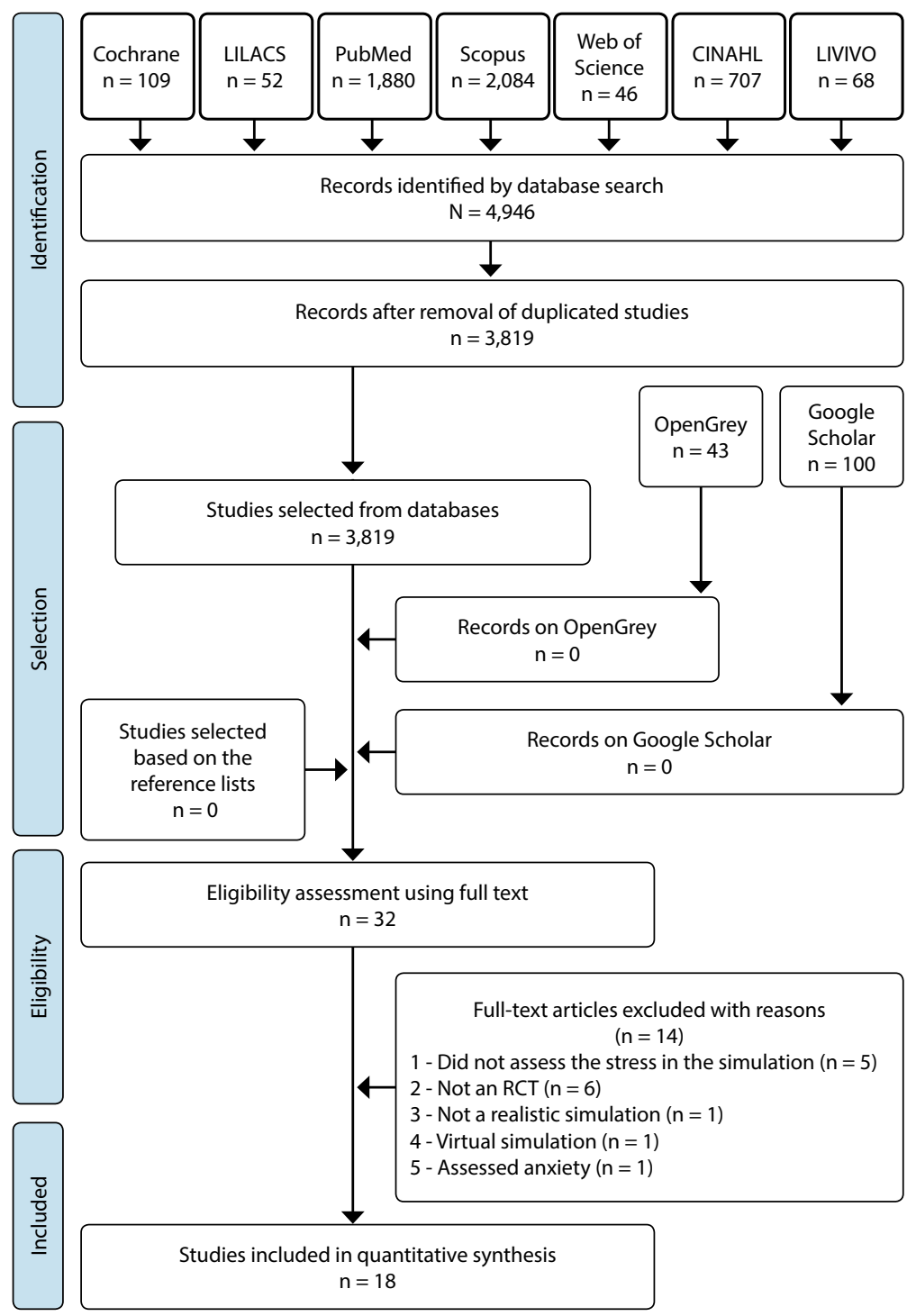

Figure 1 - Flowchart of the search process in the literature and selection criteria of the studies (adapted from Preferred Reporting Items for Systematic Reviews and MetaAnalyses - PRISMA), Brasília, Distrito Federal, Brazil, 2020 
Compared to other teaching strategies, simulation brought the participant greater concern with factors such as competence in interpersonal relationships with the patient and the team ${ }^{(34)}$. When participants act in different roles, everyone benefits from the simulated scenario in terms of learning ${ }^{(33)}$.

Participants' anxiety regarding their good performance may generate undue stress that will influence the performance negatively. Factors such as higher work overload, difficulty to accomplish tasks, and anxiety associated with good performance are the factors that may contribute to increased stress levels. Thus, the increased heart rate in the moment before the simulation is related to the exposition of an unknown and stressful task ${ }^{(40)}$.

We also identified the anticipated stress in a study, though measured by survey and salivary cortisol. In this study, simulations were more stressful than in real scenarios. Besides, salivary cortisol was already high before the simulation started and increased even more after the simulation ${ }^{(27)}$. Another study concluded that the change in salivary cortisol levels reflects a physiologic excitation related to the cognitive and emotional activation that arises even before doing the task, indicating a preparation. When the participants do not have a preparation, they present low cognitive and emotional activation, for handling the task in a way that they would normally deal with ${ }^{(28)}$.

During the transition of a simulator to the operating room, there was an increased heart rate. Thus, an increased workload increases the stress, especially if the participant still has little experience and he does not have the ability and attention skills to deal with the growing demands of the tasks that arise ${ }^{(40)}$.

Chart 2 - Characterization of the articles selected for analysis according to year, author, country, groups, sample, objective, stress measurement, area and conclusions - Brasilia, Brazil, 20200

\begin{tabular}{|c|c|c|c|c|c|c|}
\hline $\begin{array}{l}\text { Year, author, } \\
\text { country }\end{array}$ & Groups & $\mathbf{N}$ & Objective of the Study & $\begin{array}{c}\text { Stress } \\
\text { Measurement }\end{array}$ & Area & Main conclusions \\
\hline $\begin{array}{l}2018, \\
\text { Bensouda } \\
\text { et al. }{ }^{(30)} \\
\text { Canada }\end{array}$ & $\begin{array}{l}\text { IG: } 1 \text { observer during } \\
\text { simulation } \\
\text { CG: } 5 \text { observers during } \\
\text { simulation }\end{array}$ & $\begin{array}{l}\text { IG: } 24 \\
\text { CG: } 25\end{array}$ & $\begin{array}{l}\text { Obtain evidence that interns are } \\
\text { adversely affected by the presence } \\
\text { of a large audience during neonatal } \\
\text { endotracheal intubation. }\end{array}$ & Heart rate & Medicine & $\begin{array}{l}\text { The presence of the external } \\
\text { public did not negatively affect } \\
\text { the period of the simulated } \\
\text { intubation, but the presence of } \\
\text { observers not belonging to the } \\
\text { scenario was stressful. }\end{array}$ \\
\hline $\begin{array}{l}\text { 2010, } \\
\text { Bong } \\
\text { et al. } .^{(24)} \\
\text { United States }\end{array}$ & $\begin{array}{l}\text { IG: training based on } \\
\text { high fidelity simulation } \\
\text { (HFS) } \\
\text { CG: interactive } \\
\text { educational training } \\
\text { session }\end{array}$ & $\begin{array}{l}\text { IG: } 13 \\
\text { CG: } 14\end{array}$ & $\begin{array}{l}\text { Measure and compare physical and } \\
\text { biochemical markers of stress in } \\
\text { participants undergoing simulation } \\
\text { with those undergoing teaching } \\
\text { sessions/tutorials. }\end{array}$ & $\begin{array}{l}\text { Salivary } \\
\text { cortisol, heart } \\
\text { rate }\end{array}$ & $\begin{array}{l}\text { Medicine and } \\
\text { Nursing }\end{array}$ & $\begin{array}{l}\text { Regardless of the role of } \\
\text { participants in the simulation, } \\
\text { all showed high levels of } \\
\text { physiological stress. }\end{array}$ \\
\hline $\begin{array}{l}2018, \\
\text { Boostel } \\
\text { et al. }{ }^{\left({ }^{4}\right)} \text { Brazil }\end{array}$ & $\begin{array}{l}\text { IG: class followed by } \\
\text { simulation } \\
\text { CG: class followed by } \\
\text { laboratory practice }\end{array}$ & $\begin{array}{l}\text { IG: } 27 \\
\text { CG: } 25\end{array}$ & $\begin{array}{l}\text { Evaluate the perception of } \\
\text { students'stressors before and } \\
\text { after the clinical simulation or the } \\
\text { conventional practical class in the } \\
\text { laboratory. }\end{array}$ & Questionary & Nursing & $\begin{array}{l}\text { The simulation increased the } \\
\text { perception of stressors related } \\
\text { to the lack of competence and } \\
\text { the interpersonal relationship } \\
\text { when acting in front of the } \\
\text { patient, multidisciplinary team, } \\
\text { and colleagues compared to the } \\
\text { conventional practical class in the } \\
\text { laboratory. }\end{array}$ \\
\hline $\begin{array}{l}\text { 2016, } \\
\text { Demaria } \\
\text { et al. }{ }^{(35)} \\
\text { United States }\end{array}$ & $\begin{array}{l}\text { IG: simulation group } \\
\text { with death } \\
\text { CG: simulation group } \\
\text { with survival }\end{array}$ & $\begin{array}{l}\text { IG: } 13 \\
\text { CG: } 14\end{array}$ & $\begin{array}{l}\text { Describe the physiological and } \\
\text { biochemical stress response in } \\
\text { students during the simulation of a } \\
\text { patient death compared to a group } \\
\text { whose patient is programmed to } \\
\text { survive. }\end{array}$ & $\begin{array}{l}\text { Salivary } \\
\text { cortisol, DHEA } \\
\text { hormone and } \\
\text { heart rate }\end{array}$ & Medicine & $\begin{array}{l}\text { Students experienced stress } \\
\text { during high fidelity simulation; } \\
\text { there was not a negative } \\
\text { response of a scenario with death } \\
\text { compared to a survival scenario. }\end{array}$ \\
\hline $\begin{array}{l}2012, \\
\text { Finan } \\
\text { et al. }{ }^{(36)} \\
\text { Canada }\end{array}$ & $\begin{array}{l}\text { IG: HFS simulation } \\
\text { CG: low fidelity } \\
\text { simulation (LFS) }\end{array}$ & $\begin{array}{l}\text { IG: } 8 \\
\text { CG: } 8\end{array}$ & $\begin{array}{l}\text { Compare the effects of HFS versus } \\
\text { LFS on stress measurements in a } \\
\text { group of neonatology interns. }\end{array}$ & $\begin{array}{l}\text { Survey and } \\
\text { salivary } \\
\text { cortisol }\end{array}$ & Medicine & $\begin{array}{l}\text { The use of HFS and LFS } \\
\text { technology increased subjective } \\
\text { and objective stress measures. } \\
\text { HFS did not offer additional } \\
\text { benefits in terms of stress } \\
\text { modification. }\end{array}$ \\
\hline $\begin{array}{l}2015, \\
\text { Flinn } \\
\text { et al. }{ }^{(37)} \\
\text { United States }\end{array}$ & $\begin{array}{l}\text { CG: control group } \\
\text { OG: observed group } \\
\text { EG: encouraged group } \\
\text { CGi: criticized group }\end{array}$ & $\begin{array}{l}\text { CG: } 10 \\
\text { OG: } 10 \\
\text { EG: } 10 \\
\text { CGi: } 10\end{array}$ & $\begin{array}{l}\text { Compare the effects of the LFS } \\
\text { simulator versus HFS technology } \\
\text { on performance levels, objective } \\
\text { and subjective measures of stress in } \\
\text { neonatology interns. }\end{array}$ & $\begin{array}{l}\text { MBP, heart } \\
\text { rate, skin } \\
\text { conductance, } \\
\text { basal cortisol } \\
\text { and Anxiety } \\
\text { Inventory }\end{array}$ & Medicine & $\begin{array}{l}\text { The criticized group had higher } \\
\text { levels of stress compared to the } \\
\text { control group. The presence of an } \\
\text { expert evaluator produced higher } \\
\text { levels of stress for participants. }\end{array}$ \\
\hline $\begin{array}{l}2019, \\
\text { Ghazali } \\
\text { et al. }{ }^{(29)} \\
\text { France }\end{array}$ & $\begin{array}{l}\text { IG: } 9 \text { simulations for } \\
1 \text { year } \\
\text { CG: } 3 \text { simulations for } \\
1 \text { year }\end{array}$ & $\begin{array}{l}\text { IG: } 24 \\
\text { CG: } 24\end{array}$ & $\begin{array}{l}\text { Analyze physiological stress } \\
\text { according to the frequency of } \\
\text { repetition of simulations. }\end{array}$ & $\begin{array}{l}\text { Heart rate } \\
\text { variability }\end{array}$ & $\begin{array}{l}\text { Medicine, } \\
\text { nursing, } \\
\text { paramedic, } \\
\text { ambulance } \\
\text { driver }\end{array}$ & $\begin{array}{l}\text { Stress is recurrent in repeated } \\
\text { high-fidelity simulation sessions } \\
\text { in life-threatening events and } \\
\text { decreases over } 24 \text { hours. }\end{array}$ \\
\hline
\end{tabular}


Chart 2

\begin{tabular}{|c|c|c|c|c|c|c|}
\hline $\begin{array}{l}\text { Year, author, } \\
\text { country }\end{array}$ & Groups & $\mathbf{N}$ & Objective of the Study & $\begin{array}{c}\text { Stress } \\
\text { Measurement }\end{array}$ & Area & Main conclusions \\
\hline $\begin{array}{l}2009, \\
\text { Girzadas } \\
\text { et al. }{ }^{(33)} \\
\text { United States }\end{array}$ & $\begin{array}{l}\text { IG: team leader in } \\
\text { simulation } \\
\text { CG: member in } \\
\text { simulation }\end{array}$ & 38 & $\begin{array}{l}\text { Measure heart rates and stress and } \\
\text { learning perceived by participants } \\
\text { in two simulation scenarios, } \\
\text { in addition to evaluating their } \\
\text { responses to questions at the end } \\
\text { of the experiment. }\end{array}$ & $\begin{array}{l}\text { Heart rate, } \\
\text { survey }\end{array}$ & $\begin{array}{l}\text { Students } \\
\text { and medical } \\
\text { residents }\end{array}$ & $\begin{array}{l}\text { The participants' heart rate } \\
\text { increased from the pre-procedure } \\
\text { to the critical intervention. } \\
\text { Self-reported learning values } \\
\text { increased with self-reported } \\
\text { stress levels. }\end{array}$ \\
\hline $\begin{array}{l}\text { 2020, } \\
\text { Hardenberg, } \\
\text { Rana, Tori(1) } \\
\text { Australia }\end{array}$ & $\begin{array}{l}\text { IG: repeated simulation } \\
\text { sessions } \\
\text { CG: a single simulation } \\
\text { session }\end{array}$ & $\begin{array}{l}\text { IG: } 7 \\
\text { CG: } 7\end{array}$ & $\begin{array}{l}\text { Investigate whether repeated } \\
\text { exposure to a challenging clinical } \\
\text { scenario leads to a reduction in } \\
\text { stress levels. }\end{array}$ & Heart rate & Nursing & $\begin{array}{l}\text { Repeated simulation exposure } \\
\text { did not reduce stress levels } \\
\text { measured by heart rate. }\end{array}$ \\
\hline $\begin{array}{l}2013, \\
\text { Hunziker } \\
\text { et al. }{ }^{(38)} \\
\text { Switzerland }\end{array}$ & $\begin{array}{l}\text { IG: with previous } \\
\text { instructions on how to } \\
\text { deal with stress } \\
\text { CG: no previous } \\
\text { instructions on how to } \\
\text { deal with stress }\end{array}$ & $\begin{array}{l}\text { IG: } 62 \\
\text { CG: } 62\end{array}$ & $\begin{array}{l}\text { Describe stress patterns during } \\
\text { a simulation and investigate } \\
\text { perceived stress and its association } \\
\text { with coping and performance } \\
\text { strategy. }\end{array}$ & Survey & Medicine & $\begin{array}{l}\text { A brief stress coping strategy } \\
\text { moderately decreased perceived } \\
\text { stress without significantly } \\
\text { affecting performance in a CPR } \\
\text { scenario. }\end{array}$ \\
\hline $\begin{array}{l}2015, \\
\text { lgnacio } \\
\text { et al.(41) } \\
\text { Singapore }\end{array}$ & $\begin{array}{l}\text { IG: use of standardized } \\
\text { patient in the } \\
\text { simulation } \\
\text { CG: use of mannequin } \\
\text { in the simulation }\end{array}$ & $\begin{array}{l}\text { IG: } 29 \\
\text { CG: } 28\end{array}$ & $\begin{array}{l}\text { Compare the effects of using a } \\
\text { standardized patient and high- } \\
\text { fidelity mannequin on students' } \\
\text { stress levels and performance. }\end{array}$ & $\begin{array}{l}\text { Salivary alpha- } \\
\text { amylase and } \\
\text { focus group }\end{array}$ & Nursing & $\begin{array}{l}\text { Performance and stress during } \\
\text { training did not differ with or } \\
\text { without a standardized patient. } \\
\text { However, in the focus group, we } \\
\text { noticed that using standardized } \\
\text { patients in the simulation had } \\
\text { advantages over the mannequin. }\end{array}$ \\
\hline $\begin{array}{l}2017, \\
\text { Lizotte } \\
\text { et al. } \\
\text { Canada }\end{array}$ & $\begin{array}{l}\text { IG: simulation with } \\
\text { death } \\
\text { CG: simulation with } \\
\text { survival }\end{array}$ & $\begin{array}{l}\text { IG: } 21 \\
\text { CG: } 21\end{array}$ & $\begin{array}{l}\text { Evaluate the impact of simulations } \\
\text { on stress and performance both } \\
\text { during a simulation with survivors } \\
\text { and in simulated death. }\end{array}$ & $\begin{array}{l}\text { Survey, } \\
\text { salivary } \\
\text { cortisol }\end{array}$ & Medicine & $\begin{array}{l}\text { The simulation caused stress } \\
\text { without interfering with } \\
\text { performance. Having a "dead" } \\
\text { mannequin during the simulation } \\
\text { did not increase objective stress } \\
\text { or interfere with performance. }\end{array}$ \\
\hline $\begin{array}{l}2013, \\
\text { Meunier } \\
\text { et al. }{ }^{(28)} \\
\text { Belgium }\end{array}$ & $\begin{array}{l}\text { IG: with previous } \\
\text { training on } \\
\text { communication } \\
\text { CG: no previous } \\
\text { training on } \\
\text { communication }\end{array}$ & $\begin{array}{l}\text { IG: } 50 \\
\text { CG: } 48\end{array}$ & $\begin{array}{l}\text { Evaluate the effect of } \\
\text { communication training on } \\
\text { physiological arousal during an } \\
\text { adverse communication simulation. }\end{array}$ & $\begin{array}{l}\text { Heart rate, } \\
\text { salivary } \\
\text { cortisol and } \\
\text { survey }\end{array}$ & Medicine & $\begin{array}{l}\text { Communication skills training } \\
\text { affects physiological arousal } \\
\text { in a simulated adverse } \\
\text { communication task. }\end{array}$ \\
\hline $\begin{array}{l}2013, \\
\text { Pottier } \\
\text { et al. }{ }^{(39)} \\
\text { France }\end{array}$ & $\begin{array}{l}\text { IG: high stress scenario } \\
\text { CG: low stress scenario }\end{array}$ & $\begin{array}{l}\mathrm{IG}: 21 \\
\mathrm{CG}: 20\end{array}$ & $\begin{array}{l}\text { Assess the impact of subjective } \\
\text { and physiological stress on } \\
\text { student decision-making and } \\
\text { communication skills in an } \\
\text { outpatient setting. }\end{array}$ & $\begin{array}{l}\text { Scales, } \\
\text { cognitive } \\
\text { evaluation, } \\
\text { Anxiety } \\
\text { Inventory, } \\
\text { salivary } \\
\text { cortisol }\end{array}$ & Medicine & $\begin{array}{l}\text { The simulated high-stress } \\
\text { outpatient consultation is a } \\
\text { negative impact situation for } \\
\text { students, leading to failures in } \\
\text { clinical reasoning and diagnostic } \\
\text { errors. }\end{array}$ \\
\hline $\begin{array}{l}\text { 2010, Prabhu } \\
\text { et al.(40) } \\
\text { United States }\end{array}$ & $\begin{array}{l}\text { IG: previous suture } \\
\text { training } \\
\text { CG: no previous suture } \\
\text { training }\end{array}$ & $\begin{array}{l}\text { IG: } 13 \\
\text { CG: } 07\end{array}$ & $\begin{array}{l}\text { Examine the trainees' stress level } \\
\text { during the transition from the } \\
\text { simulator to the operating room } \\
\text { and its impact on performance. }\end{array}$ & $\begin{array}{l}\text { Survey, heart } \\
\text { rate, and heart } \\
\text { rate variability }\end{array}$ & Medicine & $\begin{array}{l}\text { The improper transition from the } \\
\text { simulator to the operating room } \\
\text { involving the acquired skills may } \\
\text { be a consequence of increased } \\
\text { stress and anxiety. Heart rate } \\
\text { was a better measure of stress } \\
\text { compared to heart rate variability. }\end{array}$ \\
\hline $\begin{array}{l}2017, \\
\text { Sorensen } \\
\text { et al. }{ }^{(32)} \\
\text { Denmark }\end{array}$ & $\begin{array}{l}\text { IG: in situ simulation } \\
\text { CG: clinic simulation }\end{array}$ & $\begin{array}{l}\text { IG: } 48 \\
\text { CG: } 49\end{array}$ & $\begin{array}{l}\text { Investigate the effect of simulation } \\
\text { in situ versus clinical simulation } \\
\text { on knowledge, safety, stress, } \\
\text { motivation, perception of } \\
\text { simulation, team performance, } \\
\text { and organizational impact among } \\
\text { multidisciplinary teams of obstetric } \\
\text { anesthesia. }\end{array}$ & $\begin{array}{l}\text { Survey, } \\
\text { salivary } \\
\text { cortisol }\end{array}$ & $\begin{array}{l}\text { Medicine and } \\
\text { nursing }\end{array}$ & $\begin{array}{l}\text { There was no finding that } \\
\text { education based on simulation } \\
\text { conducted in situ compared to } \\
\text { clinical simulation led to different } \\
\text { results evaluated in stress. }\end{array}$ \\
\hline $\begin{array}{l}\text { 2018, } \\
\text { Timberlake, } \\
\text { Stefanidis } \\
\text { and } \\
\text { Gardner }{ }^{(42)} \\
\text { United States }\end{array}$ & $\begin{array}{l}\text { IG: laparoscopic suture } \\
\text { training with video and } \\
\text { instructor practice } \\
\text { CG: laparoscopic suture } \\
\text { training with video and } \\
\text { practice without an } \\
\text { instructor }\end{array}$ & $\begin{array}{l}\text { IG: } 12 \\
\text { CG: } 12\end{array}$ & $\begin{array}{l}\text { Examine the impact of a specific } \\
\text { teaching technique on skill } \\
\text { acquisition and physiological stress. }\end{array}$ & $\begin{array}{l}\text { Heart rate, } \\
\text { heart rate } \\
\text { variability, } \\
\text { respiratory } \\
\text { rate }\end{array}$ & Medicine & $\begin{array}{l}\text { Students who receive surgical } \\
\text { training exhibit greater } \\
\text { performance gains compared } \\
\text { to those who do it self-directed. } \\
\text { Improvements in skill acquisition } \\
\text { correlated with increases in heart } \\
\text { rate variability. }\end{array}$ \\
\hline
\end{tabular}




\begin{tabular}{|c|c|c|c|c|c|c|}
\hline $\begin{array}{l}\text { Year, author, } \\
\text { country }\end{array}$ & Groups & $\mathbf{N}$ & Objective of the Study & $\begin{array}{c}\text { Stress } \\
\text { Measurement }\end{array}$ & Area & Main conclusions \\
\hline $\begin{array}{l}\text { 2016, } \\
\text { Waterland } \\
\text { et al. }{ }^{(31)} \\
\text { England }\end{array}$ & $\begin{array}{l}\text { IG: simulation with } 80 \\
\text { dB noises. } \\
\text { CG: simulation in } \\
\text { silence }\end{array}$ & $\begin{array}{l}\text { IG: } 35 \\
\text { CG: } 35\end{array}$ & $\begin{array}{l}\text { Determine the effect of } \\
\text { environmental noise on the } \\
\text { psychological and physiological } \\
\text { response to stress in students } \\
\text { during simulated laparoscopic } \\
\text { surgery. }\end{array}$ & $\begin{array}{l}\text { Anxiety } \\
\text { Inventory, } \\
\text { heart rate }\end{array}$ & Medicine & $\begin{array}{l}\text { Environmental noises } \\
\text { generated an increase in the } \\
\text { participants'stress response in } \\
\text { simulated laparoscopic surgery } \\
\text { environments. }\end{array}$ \\
\hline
\end{tabular}

Note: IG - intervention group; GC - control group; EG - encouraged group; OG - observed group; GCi - criticized group; HFS - high fidelity simulation; LFS - low fidelity simulation; DHEA - Dehydroepiandrosterone; $M B P$ - medium blood pressure; $R C P$ - cardiopulmonary resuscitation.

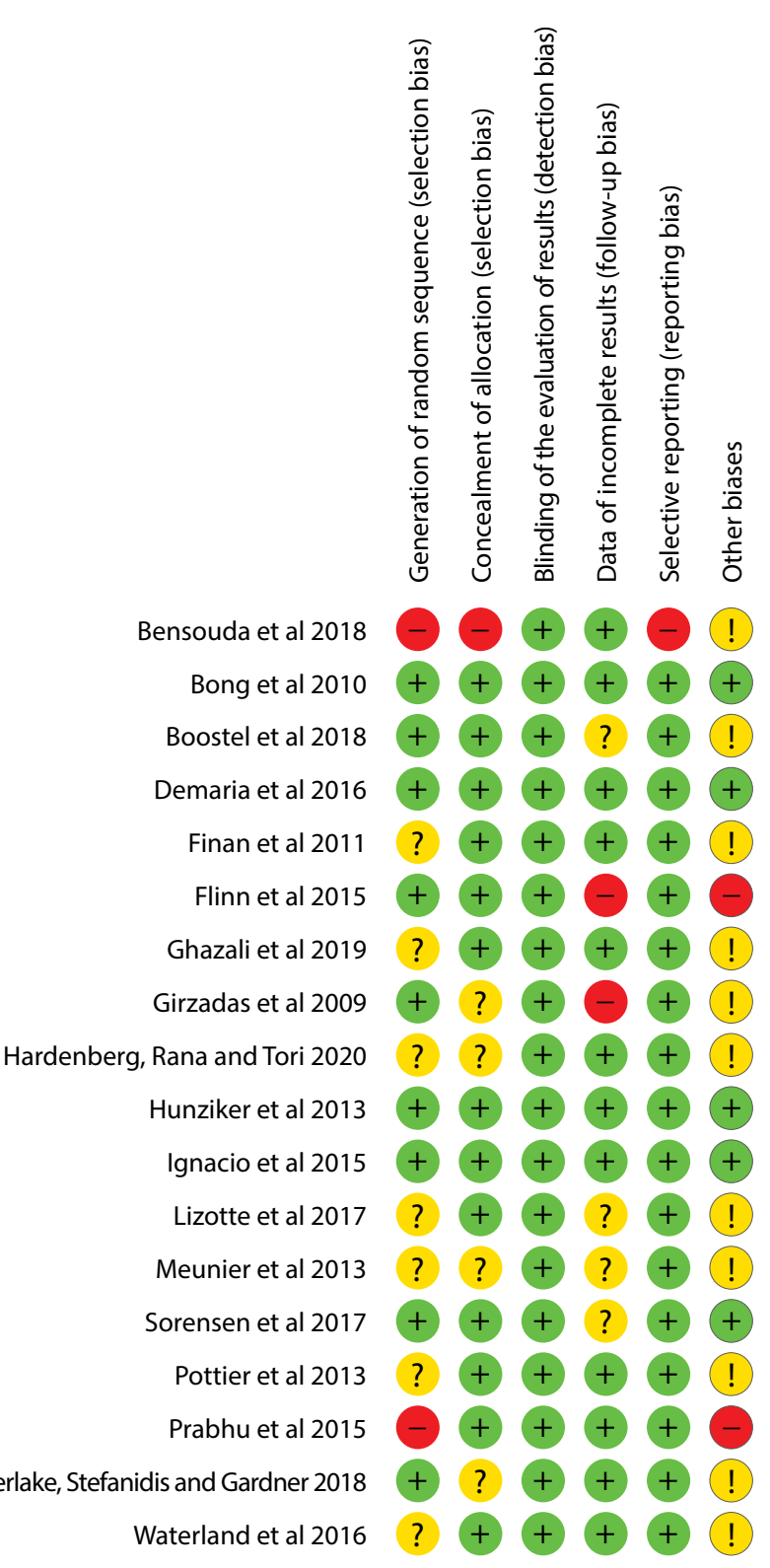

Figure 2 - Methodologic evaluation of the studies included based on the tool Cochrane Collaboration Risk of Bias, Brasilia, Distrito Federal, Brazil, 2020

\section{DISCUSSION}

\section{Summary of the evidences}

This is a systematic review about the available signs regarding the stress experienced by the participants in a realistic simulation.
A total of 12 RCTs were included and identified that the stress is present in training in different realistic scenarios. However, the beneficial level for learning and performance is still uncertain.

There is no difference in the participant's stress between the clinic and in situ simulations. Changes in simulation fidelity and scenario settings do not necessarily translate into learning. Noises do not significantly alter the stress ${ }^{(31)}$. The evaluation through scales and stress physiological parameters had similar values in some studies ${ }^{(32-33)}$; while in another, this behavior was different ${ }^{(38)}$.

One of the included studies measured the stress by the salivary amylase and suggested that the levels were not captured at their peak because some participants may take longer to produce sufficient amounts of saliva ${ }^{(41)}$. Thus, it is important a deepen study in this aspect since stress determined objectively and/or subjectively can result in an improvement or worsening in performance ${ }^{(15,43-44)}$.

It is important to evaluate the previous experiences, since factors like fear, anger, anxiety, and the strategies to face them will reflect in the level of stress of the participants during the simulation and, consequently, on their performance. The main stressors factors identified by the participants are the lack of competence and relationship difficulties ${ }^{(34)}$.

Some studies recommend the stress factors reduction in simulation ${ }^{(34,40)}$, confirming other studies that identified the negative influence of performance stress during the simulation in trauma emergency scenarios ${ }^{(43-45)}$. Other investigations identified that the stressor factor is important for learning in adverse communication, neonatal emergency, trauma, and surgery scenarios ${ }^{(27-28,33,42)}$, and it does not affect the participants' performance in neonatal resuscitation, outpatient consultation, and trauma scenarios ${ }^{(36,39,43)}$. One of the studies with surgical simulations indicates that the performance is increased with stress until a certain level, considering that after such level, performance decreases, i.e., it is beneficial to a certain extent ${ }^{(42)}$.

A study showed that low or moderate anxiety levels are associated with better performance, while high anxiety levels probably have deleterious effects on performance ${ }^{(40)}$. On the other hand, people with activated autonomic state have an improvement in memorizing events ${ }^{(46)}$, and when they get more experienced, there is less change in the physiological and psychological measures of stress ${ }^{(47-48)}$.

High cortisol levels before, during, and after a simulation reflect the physiologic excitation related to cognitive and emotional activation that properly prepare the participant to respond positively to the task ${ }^{(28)}$.

The mental stress may impair performance as far as the resources are added to the scene so that the cognitive system 
runs the risk of becoming overloaded. In a stressful situation, the attention may be directed only to the selected tasks, neglecting other potentially relevant information ${ }^{(38)}$.

Simulations reveal that, in emergencies, the leader experiences higher stress than the other team members ${ }^{(36)}$. It is also possible to confirm that the social involvement in the communication with the patient generates stress that emotionally prepares the participant for this type of task. In these cases, the use of standardized patients is more suitable for the acquisition of skills ${ }^{(41)}$.

In a simulated scenario, we still do not completely know which factor may affect the parameters related to the stress since a difficult task leads to increased workload, and increases the likelihood that the performance level will be lower and thus generate more malpractices ${ }^{(29,40)}$. In another instance, while encouraging does not improve performance, criticism can be harmful ${ }^{(37)}$.

When there are frequent repetitions in the simulation, the stress experienced in the sessions remains ${ }^{(1)}$ however, the Autonomic Nervous System activity decreases during the day in such a way that the participants are less nervous about the simulation. On the other hand, when there is a repetition of simulation only once a semester, this autonomic habituation does not happen ${ }^{(29)}$.

The presence of external people watching the execution of the task is a stressor factor. Thus, teachers need to understand the mechanisms of stress and provide resources for their management ${ }^{(30)}$.

\section{Study limitations}

The methodologic limitations of the studies included in this systematic revision should be taken into consideration. The main limitation is related to the blinding of participants that most of the studies did not use for intervention, a difficult fact to manage since the scenarios are repeated in distinct groups, and also participants usually be in the same group of studies or work. This aspect could be minimized by the blinding of the evaluator. Although simulations are designed to have a high reality, only one trial made the transition from the simulation to a real scenario in the stress assessment. Also, not all studies address the participant's previous experience with the simulation. Therefore, further surveys are necessary aiming to identify the stress effect during the simulations.

\section{Contributions to the Area}

The present revision showed that the student experiences high stress in simulation sessions, which we identified through different measures. Teachers who instruct students or health professionals during the simulation understand that the process needs to be planed carefully to make the stress generates learning instead of trauma. The study fills a gap in the knowledge in the area of simulation to understand the stress and directs new researches.

\section{CONCLUSIONS}

The studies' indications included in this systematic revision suggest that the stress is experienced at a high level in simulated scenarios. In some studies, it was beneficial for the learning process, whereas, in others, there was an indication to try to minimize whenever possible since it is recommended up to a certain level. Thus, the real benefit of the stress in simulated scenarios is uncertain since the variation of stress is imprecise in scenarios of different areas and complexities explored in the studies. There was a wide variation of the methodologic quality of the included studies. At last, more randomized clinical trials should be performed to identify the different ways to measure the stress and the academic and professional impacts related to learning.

\section{REFERENCES}

1. Hardenberg J, Rana I, Tori K. Evaluating impact of repeated exposure to high fidelity simulation: skills acquisition and stress levels in postgraduate critical care nursing students. Clin Simul Nurs. 2020;48:96-102. https://doi.org/10.1016/j.ecns.2020.06.002

2. Kiernan LC. Evaluating competence and confidence using simulation technology. 2018;48(10):45-52. https://doi.org/10.1097/01. NURSE.0000545022.36908.f3

3. Sollid SJM, Dieckman P, Aase K, Soreide E, Ringsted C, Ostergaard D. Five topics health care simulation can address to improve patient safety: results from a consensus process. J Patient Saf. 2019;15(2):111-20. https://doi.org/10.1097/PTS.0000000000000254

4. Padilha JM, Machado PP, Ribeiro A, Ramos J, Costa P. Clinical virtual simulation in nursing education: randomized controlled trial. J Med Internet Res. 2019;21(3):e11529. https://doi.org/10.2196/11529

5. Costa RRO, Medeiros SM, Coutinho VRD, Mazzo A, Araújo MS. Satisfaction and self-confidence in the learning of nursing students: randomized clinical trial. Esc Anna Nery. 2020;24(1):e20190094. https://doi.org/10.1590/2177-9465-ean-2019-0094

6. Cura SU, Kocatepe V, Yıldırım D, Kuçukakgun H, Atay S, Unver V. Examining knowledge, skill, stress, satisfaction, and self-confidence levels of nursing students in three different simulation modalities. Asian Nurs Res. 2020;14(3):158-64. https://doi.org/10.1016/j.anr.2020.07.001

7. Mesquita HCT, Santana BS, Magro MCS. Effect of realistic simulation combined to theory on self-confidence and satisfaction of nursing professionals. Esc Anna Nery. 2019;23(1):e20180270. https://doi.org/10.1590/2177-9465-ean-2018-0270

8. Ostovar S, Allahbakhshian A, Gholizadeh L, Dizaji SL, Sarbakhsh P, Ghahramanian A. Comparison of the effects of debriefing methods on psychomotor skills, self-confidence, and satisfaction in novice nursing students: a quasi-experimental study. J Adv Pharm Technol Res. 2018;9(3):107-12. https://doi.org/10.4103/japtr.JAPTR_291_18

9. Zonta JB, Eduardo AHA, Ferreira MVF, Chaves GH, Okido ACC. Self-confidence in the management of health complications at school: contributions of the in situ simulation. Rev Latino-Am Enfermagem. 2019;27:e3174. https://doi.org/10.1590/1518-8345.2909.3174 
10. Judd BK, Currie J, Dodds KL, Fethney J, Gordon CJ. Registered nurses psychophysiological stress and confidence during high-fidelity emergency simulation: effects on performance. Nurse Educ Today. 2019;78:44-49. https://doi.org/10.1016/j.nedt.2019.04.005

11. Yaribeygi H, Panahi Y, Sahraei H, Johnston TP, Sahebkar A. The impact of stress on body function: a review. Excli J. 2017;16:1057-1072. https://doi.org/10.17179/excli2017-480

12. Bajunaid K, Mullah MA, Winkler-Schwartz A, Alotaibi FE, Fares J, Baggiani M, et al. Impact of acute stress on psychomotor bimanual performance during a simulated tumor resection task. J Neurosurg. 2017;126(1):71-80. https://doi.org/10.3171/2015.5

13. Geeraerts T, Roulleau P, Cheisson G, Marhar F, Aidan K, Lallali K, et al. Physiological and self-assessed psychological stress induced by a high fidelity simulation course among third year anesthesia and critical care residents: an observational study. Anaesth Crit Care Pain Med. 2017;36(6):403-6. https://doi.org/10.1016/j.accpm.2017.06.002

14. Kubin L, Wilson CE. Effects of community volunteer children on student pediatric assessment behaviors. Clin Simul Nurs. 2017;13(7):303-8. http://dx.doi.org/10.1016/ j.ecns.2017.04.011

15. Macdougall L, Martin R, McCallum I, Grogan E. Simulation and stress: acceptable to students and not confidence-busting. Clin Teach. 2013;10(1):38-41. https://doi.org/10.1111/j.1743-498X.2012

16. Wirth MM. Hormones, stress, and cognition: the effects of glucocorticoids and oxytocin on memory. Adapt Human Behav Physiol. 2015;1(2):177-201. https://doi.org/10.1007/s40750-014-0010-4

17. Kirschbaum C, Wolf OT, May M, Wippich W, Hellhammer DH. Stress- and treatment-induced elevations of cortisol levels associated with impaired declarative memory in healthy adults. Life Sci. 1996;58(17):1475-83. https://doi.org/10.1016/0024-3205(96)00118-X

18. Seeman TE, McEwen BS, Singer BH, Albert MS, Rowe JW. Increase in urinary cortisol excretion and memory declines: MacArthur studies of successful aging. J Clin Endocrinol Metab. 1997;82(8):2458-65. https://doi.org/10.1210/jcem.82.8.4173

19. Ali N, Nater UM. Salivary Alpha-Amylase as a Biomarker of Stress in Behavioral Medicine. Int J Behav Med. 2020;27:337-42. https://doi. org/10.1007/s12529-019-09843-x

20. Assis DC, Resende DV, Marziale MHP. Association between shift work, salivary cortisol levels, stress and fatigue in nurses: integrative review. Esc Anna Nery. 2018;22(1):e20170125. ahttps://doi.org/10.1590/2177-9465-ean-2017-0125

21. Epel ES, Crosswell AD, Mayer SE, Prather AA, Slavich GM, Puterman E, et al. More than a feeling: A unified view of stress measurement for population science. Front Neuroendocrinol. 2018;49:146-69. https://doi.org/10.1016/j.yfrne.2018.03.001

22. Dearmon V, Graves RJ, Hayden S, Mulekar MS, Lawrence SM, Jones L, et al. Effectiveness of simulation-based orientation of baccalaureate nursing students preparing for their first clinical experience. J Nurs Educ. 2013;52(1):29-38. https://doi.org/10.3928/01484834-20121212-02

23. Demaria S Jr, Bryson EO, Mooney TJ, Silverstein JH, Reich DL, Bodian C, Levine Al. Adding emotional stressors to training in simulated cardiopulmonary arrest enhances participant performance. Med Educ. 2010;44(10):1006-15. https://doi. org/10.1111/j.1365-2923.2010.03775.x

24. Bong CL, Lightdale JR, Fredette ME, Weinstock P. Effects of simulation versus traditional tutorial-based training on physiologic stress levels among clinicians: a pilot study. Simul Healthc. 2010;5(5):272-8. https://doi.org/10.1097/SIH.0b013e3181e98b29

25. Cheung RY, Au TK. Nursing students' anxiety and clinical performance. J Nurs Educ. 2011;50(5):286-9. https://doi. org/10.3928/01484834-20110131-08

26. Moher D, Liberati A, Tetzlaff J, Altman DG, PRISMA Group. Preferred reporting items for systematic reviews and meta-analyses: the PRISMA statement. PLoS Med. 2009;6(7):e1000097. https://doi.org/10.1371/journal.pmed.1000097

27. Lizotte $\mathrm{MH}$, Janvier A, Latraverse V, Lachance C, Walker CD, Barrington KJ, et al. The impact of neonatal simulations on trainees' stress and performance: a parallel-group randomized trial. Pediatr Crit Care Med. 2017;18(5):434-41. https://doi.org/10.1097/PCC.0000000000001119

28. Meunier J, Merckaert I, Libert Y, Delvaux N, Etienne AM, Liénard A, et al. The effect of communication skills training on residents' physiological arousal in a breaking bad news simulated task. Patient Educ Couns. 2013;93(1):40-7. https://doi.org/10.1016/j.pec.2013.04.020

29. Ghazali DA, Breque C, Sosner P, Lesbordes M, Chavagnat JJ, Ragot S, et al. Stress response in the daily lives of simulation repeaters. A randomized controlled trial assessing stress evolution over one year of repetitive immersive simulations. PLoS One. 2019;14(7):e0220111. https://doi.org/10.1371/journal.pone.0220111

30. Bensouda B, Mandel R, Mejri A, Lachapelle J, St-Hilaire M, Ali N. Effect of an audience on trainee stress and performance during simulated neonatal intubation: a randomized crossover trial. BMC Med Educ. 2018;18(1):230. https://doi.org/10.1186/s12909-018-1338-4

31. Waterland P, Khan FS, Ismaili E, Cheruvu C. Environmental noise as an operative stressor during simulated laparoscopic surgery. Surg Laparosc Endosc Percutan Tech. 2016;26(2):133-6. https://doi.org/10.1097/SLE.0000000000000250

32. Sorensen JL, van der Vleuten C, Rosthoj S, Ostergaard D, LeBlanc V, Johansen M, et al. Simulation-based multiprofessional obstetric anaesthesia training conducted in situ versus off-site leads to similar individual and team outcomes: a randomised educational trial. BMJ Open. 2015;5(10):e008344. https://doi.org/10.1136/bmjopen-2015-008344

33. Girzadas DV Jr, Delis S, Bose S, Hall J, Rzechula K, Kulstad EB. Measures of stress and learning seem to be equally affected among all roles in a simulation scenario. Simul Healthc. 2009 Fall;4(3):149-54. https://doi.org/10.1097/SIH.0b013e3181abe9f2

34. Boostel R, Felix JVC, Bortolato-Major C, Pedrolo E, Vayego SA, Mantovani MF. Stress of nursing students in clinical simulation: a randomized clinical trial. Rev Bras Enferm. 2018;71(3):967-74. https://doi.org/10.1590/0034-7167-2017-0187 
35. DeMaria S, Silverman ER, Lapidus KA, Williams CH, Spivack J, Levine A, et al. The impact of simulated patient death on medical students' stress response and learning of ACLS. Med Teach. 2016;38(7):730-7. https://doi.org/10.3109/0142159X.2016.1150986

36. Finan E, Bismilla Z, Whyte HE, Leblanc V, McNamara PJ. High-fidelity simulator technology may not be superior to traditional low-fidelity equipment for neonatal resuscitation training. J Perinatol. 2012;32(4):287-92. https://doi.org/10.1038/jp.2011.96

37. Flinn JT, Miller A, Pyatka N, Brewer J, Schneider T, Cao CG. The effect of stress on learning in surgical skill acquisition. Med Teach. 2016;38(9):897-903. https://doi.org/10.3109/0142159X.2015.1114597

38. Hunziker S, Pagani S, Fasler K, Tschan F, Semmer NK, Marsch S. Impact of a stress coping strategy on perceived stress levels and performance during a simulated cardiopulmonary resuscitation: a randomized controlled trial. BMC Emerg Med. 2013;13:8. https://doi. org/10.1186/1471-227X-13-8

39. Pottier P, Dejoie T, Hardouin JB, Le Loupp AG, Planchon B, Bonnaud A, et al. Effect of stress on clinical reasoning during simulated ambulatory consultations. Med Teach. 2013;35(6):472-80. https://doi.org/10.3109/0142159X.2013.774336

40. Prabhu A, Smith W, Yurko Y, Acker C, Stefanidis D. Increased stress levels may explain the incomplete transfer of simulator-acquired skill to the operating room. Surgery. 2010;147(5):640-5. https://doi.org/10.1016/j.surg.2010.01.007

41. Ignacio J, Dolmans D, Scherpbier A, Rethans JJ, Chan S, Liaw SY. Comparison of standardized patients with high-fidelity simulators for managing stress and improving performance in clinical deterioration: a mixed methods study. Nurse Educ Today. 2015;35(12):1161-8. https://doi.org/10.1016/j.nedt.2015.05.009

42. Timberlake MD, Stefanidis D, Gardner AK. Examining the impact of surgical coaching on trainee physiologic response and basic skill acquisition. Surg Endosc. 2018;32(10):4183-90. https://doi.org/10.1007/s00464-018-6163-7

43. Leblanc VR, Regehr C, Tavares W, Scott AK, Macdonald R, King K. The impact of stress on paramedic performance during simulated critical events. Prehosp Disaster Med. 2012;27(4):369-74. https://doi.org/10.1017/S1049023X12001021

44. Fraser K, Huffman J, Ma I, Sobczak M, Mcllwrick J, Wright B, et al. The emotional and cognitive impact of unexpected simulated patient death: a randomized controlled trial. Chest. 2014;145(5):958-63. https://doi.org/10.1378/chest.13-0987

45. Harvey A, Nathens AB, Bandiera G, Leblanc VR. Threat and challenge: cognitive appraisal and stress responses in simulated trauma resuscitations. Med Educ. 2010;44(6):587-94. https://doi.org/10.1111/j.1365-2923.2010.03634.x

46. Maheu FS, Joober R, Lupien SJ. Declarative memory after stress in humans: differential involvement of the beta-adrenergic and corticosteroid systems. J Clin Endocrinol Metab. 2005;90(3):1697-704. https://doi.org/10.1210/jc.2004-0009

47. Detling N, Smith A, Nishimura R, Keller S, Martinez M, Young W, et al. Psychophysiologic responses of invasive cardiologists in an academic catheterization laboratory. Am Heart J. 2006;151(2):522-8. https://doi.org/10.1016/j.ahj.2005.03.044

48. Tendulkar AP, Victorino GP, Chong TJ, Bullard MK, Liu TH, Harken AH. Quantification of surgical resident stress "on call". J Am Coll Surg. 2005;201(4):560-4. https://doi.org/10.1016/j.jamcollsurg.2005.05.004 